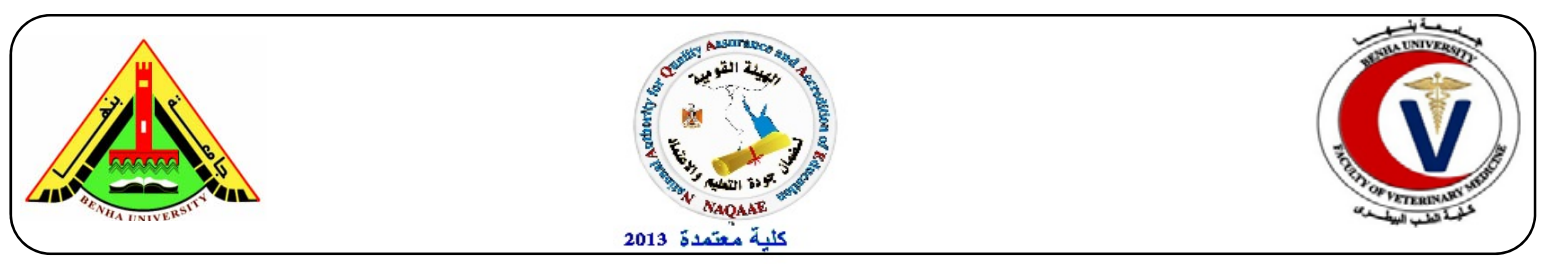

\title{
Prevalence and antimicrobial susceptibility pattern of Staphylococcus aureus isolated from dairy cattle's subclinical mastitis in EL-Sharkia Governorate.
}

\author{
${ }^{1}$ Ashraf, A. Abd El-Tawab, ${ }^{2}$ Ahmad, M. Ammar, ${ }^{3}$ Mokhtar, Abd El-Hakeem Sleim, ${ }^{1}$ Fatma, I. El \\ Hofy, ${ }^{3}$ Heba, S. S. Salem. \\ ${ }^{1}$ Bacteriology, Immunology and Mycology Dep., Fac. of Vet. Med., Benha Univ., ${ }^{2}$ Bacteriology, \\ Immunology and Mycology Dep., Fac. of Vet. Med., Zagazig Univ., ${ }^{3}$ Animal Health Research Institute \\ (Zagazig branch).
}

\begin{abstract}
A B S T R A C T
Subclinical mastitis is a disease of major economic importance to dairy industry causing reduced milk quality and loss in its production. Therefore, the present study was carried out for isolation and identification the main pathogen responsible for this disease and detection the drug of choice. A total of 475 milk samples of lactating dairy cows were collected from different localities in El-Sharkia Governorate, and subjected to physical, chemical tests (California mastitis test (CMT) as well as Somatic cell count (SCC), bacteriological examination and antimicrobial susceptibility pattern. The prevalence of subclinical mastitis at cow level was $21 \%$ (100/475). Accurately 80 Staphylococcal isolates were identified with prevalence of $61 \%$ S. aureus through beta hemolysis and coagulase positive. The obtained S. aureus isolates were highly sensitive to vancomycin, gentamicin, ciprofloxacin and chloramphenicol with percentages of $93.4 \%, 83.6 \%, 82 \%$ and $80.3 \%$, respectively. Meanwhile, high frequency of resistance was observed to oxacillin, erythromycin and tetracycline, with percentages of $59 \%, 55.7 \%$, and $47.5 \%$, respectively. Therefore, the main choice drugs for subclinical mastitis were vancomycin and gentamicin.
\end{abstract}

Keywords: Subclinical mastitis, California mastitis test, Antibiotic susceptibility.

(http://www.bvmj.bu.edu.eg)

(BVMJ-30(1): 11-19, 2016)

\section{INTRODUCTION}

$\mathrm{S}$ ubclinical mastitis is a major problem affecting dairy animals all over the world. It causes enormous losses for dairy animals through reduced milk quality, poor product hygiene and undesirable changes in the milk's composition and consequently influences the national income of the country (Kasozi et al., 2014). Subclinical mastitis is characterized by absence visible changes in the milk appearance and is the most prevalent form in dairy herds, detecting by the CMT and increase in SCC (Oliveira et al., 2011). Staphylococcus aureus seems to be the predominant organism causing subclinical mastitis (Kader et al., 2002). More than 200 infectious causes of bovine mastitis are known to date and the commonest pathogens in large animals are Staphylococcus aureus, Streptococcus agalactiae, other Streptococcus and coliforms (Kader et al., 2002 and Sharma and Maiti, 2010). However, S. aureus has emerged as one of the most prevalent pathogens which, once established in the mammary gland is difficult to eradicate (Nickerson et al., 1995). Further S. aureus is Gram positive producing smooth, circular colonies, convex and lustrous; size of the colony may be $0.5-1.5 \mu \mathrm{m}$ in diameter. Under microscope, it appears like irregular three dimensional bunches of grapes like cluster of cells. The colony pigmentation may vary from grey, grey white, grey white 
with yellowish to orange shades and in blood agar typical $\beta$ - hemolysis may be produced; depending on the growth condition (Sushma et al., 2012). Staphylococcus aureus is often responsible for intra-mammary infection in bovine and is the main etiological agent of contagious clinical and subclinical mastitis in dairy herds (Gilbert et al., 2006).

The aim of this work directed to isolate and identify the main causative agent from bovine subclinical mastitis in dairy farms at Sharkia Governorate beside detection antimicrobial susceptibility pattern for these isolates.

\section{MATERIAL AND METHODS}

\subsection{Samples collection}

Actually, 475 milk samples (360 cows were picked out from four varied dairy farms in addition to 115 individual cases of dairy cows admitted by holders to Clinic of Faculty of Veterinary Medicine, Zagazig University and Animal Health Research Institute, Zagazig) were collected during the period extended from January 2013 until May 2014. These collected samples were aseptically put into sterile screw capped tubes, kept in icebox and transferred to the laboratory.

\subsection{Mastitis markers}

a) The California Mastitis Test (CMT):

The milk samples were tested by CMT for subclinical mastitis according to Schalm et al., (1971). CMT scored from one to five corresponding to no reaction, trace, mild reaction, moderate reaction, strong reaction, respectively. Cows were considered positive for SM when at least one quarter turned out to be positive for CMT.

b) Somatic cell count (SCC):

The relevant portion of each milk sample was examined for SCC according to Zecconi et al., (2006), using automatic reader (Bently Soma count, U.S.A).

\subsection{Bacteriological examination}

A loopful of each sample is cultured onto nutrient agar (oxoid) then stained by Gram's stain (Murray et al., 2006); Subculturing onto mannitol salt agar, Baird Parker agar (Baired-Parker, 1997) and blood agar (Cruickshank et al., 1975). Each colony showed typical character of $S$. aureus and Gram positive reaction was subjected to biochemical identification (catalase and coagulase tests).

\subsection{Antimicrobials sensitivity tests}

Determination of the susceptibility of isolated Staphylococci to some antimicrobial agents was applied by disc diffusion method on Mueller Hinton agar (Barry and Berry, 1985). All isolates of $S$. aureus were tested with 10 different antimicrobial agents: vancomycin (VA), oxacillin (OX), clindamycin (DA), erythromycin (E), gentamycin $(\mathrm{CN})$, ciprofloxacin (CIP), sulphamethaxazoltrimethoprim (SXT), ceftriaxone (CRO), chloroamphenicol (C), tetracycline (TE). Metric ruler was used to measure the diameter of the zone of inhibition according to NCCLs, 2007 and CLSI, 2014.

\section{RESULTS}

\subsection{Incidence of subclinical mastitis in cows:}

The current study revealed that out of 475 dairy cattle an overall prevalence of SM based on CMT and SCC was $21 \%$ (100/475) from different localities in ELSharkia Governorate (Table 1).

\subsection{Cultural, morphological and biochemical characters of isolated S. aureus:}

Eighty staphylococcus isolates were recovered from all examined subclinical mastitic samples and identified by conventional methods. All isolates grew on mannitol salt agar were Gram positive, non motile, non spore forming and arranged in grape like clusters but only 61/80 gave yellow colonies on mannitol salt agar (ferment salt agar). On Baird Parker medium, black small shiny, convex $1 \mathrm{~mm}$ 
colonies after 24 hours and large $2.5 \mathrm{~mm}$ after 48 hours surrounded by an opalescent ring only in $S$. aureus. Additionally, all isolates were tube coagulase test positive, $\beta$ haemolytic, catalase positive and produced characteristic pigments. Moreover, it was noted that the pigmentation on milk agar must not be used as a sole mean for detection of $S$. aureus as 10 coagulase positive isolates gave B-haemolysis on sheep blood agar but they gave white pigmentation on milk agar (Table2).

\subsection{Antimicrobial sensitivity test:}

Antimicrobial sensitivity pattern for $61 \mathrm{~S}$. aureus isolates, which recovered from sub clinically mastitic milk samples, revealed that the majority were susceptible to vancomycin, gentamicin, ciprofloxacin, chloramphenicol, with percentages of $93.4 \%, \quad 83.6 \%, \quad 82 \%$ and $80.3 \%$, respectively. Moreover, moderate sensitivity was observed to trimethoprim sulphathoxazole, clindamycin, tetracycline, with percentages of $65.6 \%, 60.7 \%$, and $47.5 \%$, respectively. Furthermore, frequent resistance was observed to oxacillin, erythromycin, and tetracycline, with percentages of $59 \%, 55.7 \%$, and $47.5 \%$, respectively (Table 3 ).

Table (1): Occurrence of S. aureus in milk samples from various localities in El- Sharkia Governorate.

\begin{tabular}{|c|c|c|c|c|}
\hline $\begin{array}{l}\text { Samples } \\
\text { type }\end{array}$ & Origin of milk sample & $\begin{array}{c}\text { Number of } \\
\text { milk samples }\end{array}$ & $\begin{array}{c}\text { Number of milk } \\
\text { samples analyzed } \\
\text { (CMT positive) (\%) }\end{array}$ & $\begin{array}{c}\text { Number of } \\
\text { samples showing } \\
\text { S. aureus (\%) }\end{array}$ \\
\hline $\begin{array}{l}\text { Samples } \\
\text { from }\end{array}$ & 1-Abo Mandoor farm & 75 & $\begin{array}{c}16 \\
(21.33 \%)\end{array}$ & $\begin{array}{c}6 \\
(37.50 \%)\end{array}$ \\
\hline $\begin{array}{l}\text { apparently } \\
\text { healthy }\end{array}$ & 2-El salhia farm & 95 & $\begin{array}{c}26 \\
(27.37 \%)\end{array}$ & $\begin{array}{c}26 \\
(100 \%)\end{array}$ \\
\hline cows & 3-El Hosania farm & 80 & $\begin{array}{c}5 \\
(6.25 \%)\end{array}$ & $\begin{array}{c}0 \\
(0 \%)\end{array}$ \\
\hline & 4-Sami Assad farm & 110 & $\begin{array}{c}10 \\
(9.09)\end{array}$ & $\begin{array}{c}9 \\
(90 \%)\end{array}$ \\
\hline & $\begin{array}{l}\text { 5-Animal Health Research } \\
\text { Institute, Zagazig }\end{array}$ & 50 & $\begin{array}{c}25 \\
(50 \%)\end{array}$ & $\begin{array}{c}13 \\
(52 \%)\end{array}$ \\
\hline & $\begin{array}{l}\text { 6-Clinic of Faculty of } \\
\text { Veterinary Medicine, } \\
\text { Zagazig University }\end{array}$ & 65 & $\begin{array}{c}18 \\
(27.69 \%)\end{array}$ & $\begin{array}{c}7 \\
(38.8 \%)\end{array}$ \\
\hline Total & & 475 & $\begin{array}{c}100 \\
(21.05 \%)\end{array}$ & $\begin{array}{c}61 \\
(61 \%)\end{array}$ \\
\hline
\end{tabular}


Abd El-Tawab et al. (2016)

Table (2): Phenotypical characteristics of staphylococci isolated from subclinical mastitic milk.

\begin{tabular}{|c|c|c|c|c|c|c|c|c|c|c|c|}
\hline \multirow[t]{2}{*}{$\begin{array}{c}\text { Total } \\
\text { milk } \\
\text { samples }\end{array}$} & \multirow[t]{2}{*}{$\begin{array}{c}\text { CMT } \\
\text { positive }\end{array}$} & \multirow{2}{*}{$\begin{array}{c}\text { No. of } \\
\text { staphylococci } \\
\text { grown on to } \\
\text { MSA }\end{array}$} & \multirow{2}{*}{$\begin{array}{c}\text { No. of } \\
\text { MSA } \\
\text { fermentor } \\
\text { isolates }\end{array}$} & \multirow{2}{*}{$\begin{array}{l}\text { Bacteriological } \\
\text { aspect } \\
(\mathrm{G}+\mathrm{ve}, \text { cocci, } \\
\text { grape like } \\
\text { clusters })\end{array}$} & $\%$ of pig & ment pr & duction & \multicolumn{2}{|c|}{$\begin{array}{c}\text { Baired parker } \\
\text { (black } \\
\text { colonies) }\end{array}$} & \multirow[t]{2}{*}{$\begin{array}{c}\text { Catalase } \\
\text { test } \\
\text { (positive) }\end{array}$} & \multirow{2}{*}{$\begin{array}{c}\beta \text {-haemolytic } \\
\text { and } \\
\text { coagulase } \\
\text { positive }\end{array}$} \\
\hline & & & & & $\begin{array}{l}\text { Golden } \\
\text { Yellow }\end{array}$ & White & $\begin{array}{l}\text { Lemon } \\
\text { Yellow }\end{array}$ & $\begin{array}{l}\text { With } \\
\text { clear } \\
\text { halo }\end{array}$ & $\begin{array}{l}\text { No } \\
\text { halo }\end{array}$ & & \\
\hline 475 & 100 & $\begin{array}{c}80 / 100 \\
(80 \%)\end{array}$ & $61 / 80$ & $61 / 80$ & $51 / 80$ & $29 / 80$ & $0 / 80$ & $61 / 80$ & $19 / 80$ & $61 / 80$ & $61 / 80$ \\
\hline
\end{tabular}


Table (3): Result of antibacterial sensitivity test of $61 \mathrm{~S}$. aureus isolates recovered from subclinical mastitic milk samples of cows against different antibacterial agents

\begin{tabular}{|c|c|c|c|}
\hline Antimicrobial agents & Sensitive & Intermediate & Resistant \\
\hline \multirow{3}{*}{ Vancomycin (VA 30 $\mu \mathrm{g} / \mathrm{ml})$} & No. & No. & No. \\
\hline & 57 & 0 & 4 \\
\hline & $93.4 \%$ & $0 \%$ & $6.6 \%$ \\
\hline \multirow[t]{2}{*}{ Oxacillin $(\mathrm{OX} 30 \mu \mathrm{g} / \mathrm{ml})$} & 16 & 9 & 36 \\
\hline & $26.22 \%$ & $14.7 \%$ & $59 \%$ \\
\hline \multirow[t]{2}{*}{ Clindamycin (DA $2 \mu \mathrm{g} / \mathrm{ml}$ ) } & 37 & 8 & 16 \\
\hline & $60.7 \%$ & $13.1 \%$ & $26.2 \%$ \\
\hline \multirow[t]{2}{*}{ 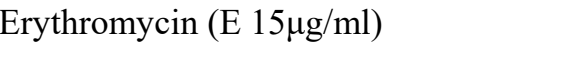 } & 20 & 7 & 34 \\
\hline & $32.8 \%$ & $11.5 \%$ & $55.7 \%$ \\
\hline \multirow[t]{2}{*}{ Gentamicin $(\mathrm{CN} 10 \mu \mathrm{g} / \mathrm{ml})$} & 51 & 0 & 10 \\
\hline & $83.6 \%$ & $0 \%$ & $16.4 \%$ \\
\hline \multirow[t]{2}{*}{ Ciprofloxacin (CIP 5 $5 \mathrm{~g} / \mathrm{ml})$} & 50 & 0 & 11 \\
\hline & $82 \%$ & $0 \%$ & $18 \%$ \\
\hline \multirow{2}{*}{$\begin{array}{l}\text { Sulfamethoxazole }+ \text { trimethoprim } \\
(\mathrm{SXT} 25 \mu \mathrm{g} / \mathrm{ml})\end{array}$} & 40 & 5 & 16 \\
\hline & $65.6 \%$ & $8.2 \%$ & $26.2 \%$ \\
\hline \multirow[t]{2}{*}{ Ceftriaxone $(\mathrm{CRO} 30 \mu \mathrm{g} / \mathrm{ml})$} & 15 & 30 & 16 \\
\hline & $24.6 \%$ & $49.2 \%$ & $26.2 \%$ \\
\hline \multirow[t]{2}{*}{ Chloramphenicol (C 30 $\mu \mathrm{g} / \mathrm{ml})$} & 49 & 1 & 11 \\
\hline & $80.3 \%$ & $1.6 \%$ & $18 \%$ \\
\hline \multirow[t]{2}{*}{ Tetracycline (TE $30 \mu \mathrm{g} / \mathrm{ml}$ ) } & 29 & 6 & 26 \\
\hline & $47.5 \%$ & $9.8 \%$ & $47.5 \%$ \\
\hline
\end{tabular}

\section{DISCUSSION}

Mastitis, a complex disease, even at subclinical stage has a major economic impact on the dairy industry (Mir et al., 2014). Staphylococcal mastitis was the commonest and economically the greatest concern wherever dairy farming practiced the chief reservoir of bacterium was an infected udder (Tarfarosh and Purohit, 2008). In this study, the prevalence of subclinical mastitis was $21 \%(100 / 475)$ in El-Sharkia Governorate. This result was nearly near to Abou-Zaid and Bahout, (1993) who reported that the prevalence of subclinical mastitis per animal was $20.6 \%$ and $21.2 \%$. This result was somewhat higher than that obtained by Abdel-Rady and Sayed (2009) (19.14\%), El- Seedy et al., (2010) (14.5\%) and lower than that obtained by EL-Khabaz et al., (2011) (31.6\%) and Elhaig and Selim (2015) $(71.6 \%)$ in Egypt. Moreover, the incidence of subclinical mastitis differed among countries such as $8.3 \%$ in Tanzania (Karimuribo et al., 2005), $74.49 \%$ in Bangladesh (Islam et al., 2014) and 87.9\% in United States (Kasozi et al., 2014). The difference in prevalence of subclinical mastitis observed between the reports from different parts and the present study could be attributable to differences in farm management practices and husbandry condition in the area and lack of awareness of farmers to the loss caused by mastitis (Radostitis et al., 2000). In this study, phenotypic identification revealed the incidence of $61 \%$ Staphylococcus aureus isolates $61 \%(61 / 100)$ was isolated from subclinical mastitis; this result was nearly consistent with Gianneechini et al., (2002) and Marija, et al., (2014) with ratio $62.8 \%$ and $56 \%$, respectively. On the other hand, this prevalence rate is higher than that recorded in Egypt (Islam et al., 2014; AbdelKareem, 2015; Elhaig and Selim, 2015) (11.64\%, 17.3\%, $38.3 \%$, respectively); 8.0\% in Colombia by Ramírez et al., (2014); 
$16.6 \%$ in Ugandan by Kasozi et al., (2014); $16.9 \%$ in China by Yang et al., (2015). Meanwhile this prevalence rate was somewhat lower than that recorded in Egypt by Abd El Tawab et al., (2015) (69\%) and recorded in Brazil by Santos et al., (2014) $(71.2 \%)$. The high incidence of S. aureus is indicative of poor hygienic measures during production, handling and distribution, stated in the findings of Zakary et al., (2011). In the current data of antibiogram revealed that vancomycin (toxic glycopeptides), gentamycin are the drugs of choice for isolates as reported previously (Belayneh et al., 2014 and Abdel-Kareem, 2015). Moreover, $59 \%$ of S. aureus isolates were resistant to methicillin (MRSA) (oxacillin) as reported previously (Tapleton and Tylor, 2002 and Waters et al., 2011). This ratio is highr than Brînda et al., 2010 (52\%) while lower than El-Deen, et. al., (2014) and Abdel-Kareem, (2015) with ratio $100 \%$. The obtained methicillin resistance attributed to the inhibition of penicillin binding proteins (PBPs) that are involved in the synthesis of peptidoglycan, an essential mesh like polymer that surrounds the cell, through the expression of a foreign PBPs (PBP2). Allthough several authers recorded absolute susceptability to oxacillin by Wang et al., (2014) and Jahan et al., (2015). MRSA are often multidrug resistant, therefore, infection is either impossible to treat or requires prolonged duration of treatment. In this study, all isolates were moderately susceptible to sulphamethoxazoletrimethoprim, clindamycin (potent lincomycin) and ceftriaxone, which disagreed with Khakpoor et al., (2011) and Wang et al., (2014).

\section{CONCLUSION}

In light of the results, the present study has focused on the incidence of staphylococcal subclinical mastitis in El-Sharkia Governorate and mentioned that vancomycin, gentamycin ciprofloxacin and chloramphenicol are the drugs of choice for these cases in dairy herds.

\section{REFERENCES}

Abdel-Kareem, 2015. Detection of antimicrobial and antiseptic resistance genes among multidrug resistant Staphylococcus aureus. Ph.D. of Bacteriology. Faculty of Veterinary Medicine, Zagazig University.

Abdel-Rady, A., Sayed, M. 2009. Epidemiological studies on subclinical mastitis in dairy cows in Assiut Governorate. Veterinary World, 2 (10):373-380.

Abd EL-Tawab, A.A., Abou El-Roos, N.A., El-Gendy, A.A.M. 2015. Bacteriological and molecular studies on Staphylococcus aureus isolated from raw milk. Benha veterinary medical journal, 28 (1):88-97.

Abou- Zaid, A.A., Bahout, A.A. 1993. Studies on subclinical mastitis in cattle. J. Egy. Vet. Med. Ass., 53(1\&2): 251259.

Baired-Parker, A.C. 1997. Methods for identifying Staphylococci and Micrococci. identification methods for microbiologist $2^{\text {nd }}$ ed. Skinner, F. and Love Lock.D., PP.201-209, Society for applied Bacteriology Technical series No. 14, London and New aYork, Academic Press.

Barry, A.L., Berry, C. 1985. Susceptability tests diffusion test procedures 978987. In Hauster, E.H and Shadomy, H.J. (ed).Manual of clinical microbiology.4th

Belayneh, R.; Belihu, K., Tesfaye, A. 2014. Microbiological study on bacterial causes of bovine mastitis and its antibiotics susceptibility patterns in East Showa Zone, Akaki district, Ethiopia. Journal of Veterinary Medicine and Animal Health, 6(4):116-122.

Brînda, M.; Herman, V., Faur, B. 2010. Antimicrobial sensitivity of some 
Staphylococcus aureus strains from bovine mastitis. LUCRĂRI stiintifice MEDICINĂ VETERINARĂ VOL. XLIII (1):102-105.

CLSI (Clinical and Laboratory Standards Institute). 2014. Performance standards for antimicrobial susceptibility testing, Twenty Fourth Informational Supplement. M100S24, 34 (1).

Cruick Shank, R.; Duguid, J.P.; Marmoin, B.P. Swain, R.H.A. 1975. Medical microbiology.The practice of medical microbiology.12 Editions, Vol.II. Churchill, Edinburgh., p.434.

El-Deen, M. M., El-Gohary A. H. N., ElBably M. A., Mohamed A. A. 2014. Invitro sensitivity of mastitis causing pathogens isolated from some dairy farms in Dakhlia Governorate to certain antibiotics and antiseptics commonly used in veterinary practices. 8th Int. Conf., MANSOURA

Elhaig, M.M., Selim, A. 2015. Molecular and bacteriological investigation of subclinical mastitis caused by Staphylococcus aureus and Streptococcus agalactiae in domestic bovids from Ismailia, Egypt. Trop. Anim. Health Prod., 47(2):271-6.

EL-Khabaz, K. A.S., Hussien, M.F., Abd-El Naser, E. M., Ahmed, H. A. 2011. Studying the occurrence of clumping factor gene in S. aureus isolated from cases of subclinical mastitis and the effect of such pathogen on milk composition. Animal Health Research Institute, Assiut branch and biotechnology Research Dept.

EL-Seedy, F. R., EL-Shabrawy, M., Hakim, A. S., Dorgham, S. M., Nagwa, S., Bakry, M. A., Osman, N. M. N. 2010. Recent techniques used for isolation and characterization of Staphylococcus aureus from mastitic cows. J. Am. Sci., 6, 701-708.

Gianneechini, R., Concha, C., Rivero, R., Delucci, I., Moreno López, J. 2002. Occurrence of clinical and subclinical mastitis in dairy herds in the west littoral region in Uruguay.Acta. Vet. Scand., 43(4): 221-230.

Gilbert, F.B., Fromageau, A., Gelineau, L., Poutrel, B. 2006. Differentiation of bovine Staphylococcus aureus isolates by use of polymorphic tandem repeat typing. Vet. Microbiol., 117: 297-303.

Islam, N.N., Farzana, Z., Chowdhury, A.M.M.A, Mannan, A., Kamaruddin, K.M., Siddiki, A.M.A.M.Z., Uddin, I. 2014. Characterization of bovine subclinical mastitis caused by Staphylococcus aureus in Southern Bangladesh by bacteriological and molecular approaches. Asian J. Biol. Sci., 7(1): 1-12.

Jahan, M., Rahman, M., Md. Parvej, S., Shah Ziqrul Haq Chowdhury, S. Md. Z.H., Haque, Md. E., Talukder, Md. A.K., Ahmed, S. 2015. Isolation and characterization of $S$. aureus from raw cow milk in Bangladesh. J. Adv. Vet. Anim. Res., 2(1): 49-55.

Kader, M. A., Samad, M. A., Seha, S., Taleb, M. 2002. Prevalence and etiology of subclinical mastitis with antibiotic sensitivity to isolated organisms among Milch cows in Bangladesh. I.J.D.S., 55(4): 218-223.

Karimuribo, E.D., Kusiluka, L.J, Mdegela, R.H., Kapaga, A.M., Sindato, C., Kambarage, D.M. 2005. Studies on mastitis, milk quality and health risks associated with consumption of milk from pastoral herds in Dodoma and Morogoro regions, Tanzania.J. Vet. Sci., 6(3):213-21.

Kasozi, K.I., Matovu, E., Tayebwa, D.S., Natuhwera, J., Mugezi, I., Mahero, M. 2014. Epidemiology of increasing hemo parasite burden in Ugandan cattle. Open Journal of Veterinary Medicine, 4, 220-231.

Marija, J. Pajić, Zoran B. Rašić, Branko, M. Velebit, Branko M. VelebitStanko, F. Boboš, Mira, M. MihajlovićUkropina, Miodrag, Ž. Radinović, Annamaria, L. Galfi, Jelena, M. Petković, 
Snježana I. Trojačanec. 2014. The prevalence of methicillin resistance and Panton Valentine leukocidin synthesis genes in eukocidin synthesis genes in Staphylococcus aureus isolates ofbovine and human origin. Veterinarskiarhiv 84 (3), 205-214.

Mir, A.Q., Bansal, B. K., Gupta, D. K. 2014. Subclinical mastitis in machine milked dairy farms in Punjab: prevalence, distribution of bacteria and current antibiogram. Veterinary World, EISSN, 7: 2231-0916.

Murray, P.R.; Rosenthal, K.S., Pfaller, M.A. 2006. Microbiologia Médica. Rio deJaneiro, Elsevier: 979.

Nickerson, S.C., Owens, W.E., Boddie, R.I. 1995. Mastitis in dairy heifers: Initial studies on prevalence and control. J. Dairy Sci., 78: 1618.

NCCLS National Committees for Clinical Laboratory Standard (NCCLs). 2007 Performance standards for antimicrobial disk susceptibility tests, document M100-S21, Pennsylvania.

Oliveira, C.M.C., Sousa, M.G.S., Silva, N.S., Mendonça, C.L., Silveira, J.A.S., Oaigen, R.P., Andrade, S.J.T., Barbosa, J.D. 2011. Prevalence and etiology of bovine mastitis in dairy region of Rondon do Pará. Pesq. Vet. Bras., 31(2): 104-110.

Radostits, O. M., Gay, C. C., Blood, D. C., Hinchcliff, K. W. 2000. Veterinary Medicine; A Textbook of Diseases of Cattle, Sheep, Pigs, Goats and Horses. $97^{\text {th }}$ Edition. W. B. Saunders. London. pp. 603-660.

Ramírez, N.F., Keefe, G., Dohoo, I., Sánchez, J., Arroyave, O., Cerón, J., Jaramillo, M., Palacio, L.G. 2014. Herd and cow level risk factors associated with subclinical mastitis in dairy farms from the high plains of the northern Antioquia, Colombia. Journal of Dairy Science, 97 (7): 4141-4150.

Santos, V.M., Martins, H.B., Rezende, I.S., Barbosa, M.S., Andrade, E.F., Souza, S.G., Campos, G.B., Oliveira, P.S.,
Sousa, D.S., Da Silva, D.C.C., Amorim, A.T., Timenetsky, J., Cruz, M.P., Yatsuda, R., Marques, L.M. 2014. Virulence factor profile of Staphylococcus aureus isolated from bovine milk from Brazil. Food and Nutrition Sciences, 5: 1496-1505.

Schalm, O. W., Carrol, E., Jain, N.C. 1971.Bovine mastitis.1st Ed. Lea and Febiger, Philadelphia, USA.pp: 360

Sharma, N. and Maiti, 2010.Incidence, etiology and antibiogram of subclinical mastitis in cows in drug. Chhattisgarh.Indian J. Vet. Res., 19: 45-54.

Sushma, K., Mahalakshmi, M.R., Sridevi, M. 2012. Morphological and biochemical characteristics and antibiotic resistance pattern of Staphylococcus aureus isolated from milk samples. International Journal of Nutrition, Pharmacology and Neurological Diseases, 2: 70-73.

Tapleton and Taylor, 2002. Methicillin resistance in Staphylococcus aureus. Sci. Prog., 85(1): 57-72.

Tarfarosh, M.A., Purohit, S. K. 2008. Isolation of Candida spp from mastitic cows and 006Dilkers.Online veterinary journal. 3(2): 28.

Wang, W., Yu, X., Yang, X., Mei, L., Guan, W., Ma, G., Li, W.,Guo, Y. 2014. Antimicrobial resistance profiles and genetic diversity of bovine Staphylococcus aureus isolated in 5 provinces of China in 2013. Zhonghua Yu Fang Yi XueZaZhi.; 48(5):406-411.

Waters, A.E., Cuomo, T.C., Buchhagen, J., Cindy, M., Watson, L., Pearce, K., Lance B-Price. 2011. Multidrug resistant Staphylococcus aureus in US meat and poultry. Clinical Infectious Diseases, 1-4.

Yang, F.L., Shan, X. L., Liang, X.W., Zhang, X.F., Qiu, G.S., Yang, B.Z. 2015. Detection of virulence associated genes in Staphylococcus aureus isolated from bovine clinical mastitis milk sample in Gaungxi. 
Trop. Anim. Health prod., 44(8):1821-6.

Zakary, E., Marionette, M., Nassif Z, Mohammed, G.M.O. 2011. Detection of Staphylococcus aureus in bovine milk and its product by real time PCR assay. Global Journal of
Biotechnology \& Biochemistry, 6: 171-177.

Zecconi, A., Cesaris, L., Liandris, E., Dapra, V., Piccinini, R. 2006. Role of several $S$. aureus virulence factors on the inflammatory response in bovine mammary gland. Microb. Pathog., 40(4): 177-183. 